\title{
IMPLEMENTASI KEBIJAKAN PERLINDUNGAN LAHAN PERTANIAN PANGAN BERKELANJUTAN DI KOTA MAKASSAR
}

\author{
Ahmad Syawal $^{1}$, H.Muhlis Madani ${ }^{2}$, Nuryanti Mustari ${ }^{3}$ \\ Universitas Muhammadiyah Makassar \\ e-mail: syawal@gmail.com
}

\begin{abstract}
The present study aims to understand and analyze implementation of sustainable food agriculture land protection policies in Makassar city. This study uses qualitative method through case-study approach, and uses observation instruments, interviews and documentation to collect data. Informants were selected by purposive sampling, which is furthermore analyzed by data reduction, data presentation, and drawing conclusion. The result obtained from this research figures out that Makassar city government does not have a Regional Regulation (PERDA), that organize spatial planing of Makassar city (RTRW) regarding the protection of sustainable agricultural food land in Makassar City. Meanwhile, there is Regional Regulation number 4 of 2015 concerning regional spatial planning of Makassar city which explains that there is an area in Makassar for agricultural area, as regulate in article 72 paragraph (2) that some of the Biringkanaya sub-districts with an area 168,79 hectares is only as a planed or as a cultivated agricultural area which is still in the planning stage, and can be transferred or managed to other things later. The Makassar city government is still in the process of ownership of agricultural land in Makassar city, and is still in the stage of budgeting and formulating a plan to procure a sustainable agricultural food protection area in Makassar City which will be included in the preparation of the new Makassar City regional regulations.
\end{abstract}

Keywords: Policy, Land conservation, Agriculture

\begin{abstract}
Abstrak
Penelitian ini bertujuan untuk mengetahui dan menganalisa Implementasi kebijakan perlindungan lahan pertanian pangan berkelanjutan di Kota Makassar. Penelitian ini menggunakan metode kualitatif, dengan pendekatan studi kasus, penilaian ini menggunakan instrument observasi, wawancara dan dokumentasi. Informan dipilih secara purposive sampling. Kemudian teknik analisa data melalui reduksi data, penyajian data, dan penarikan kesimpulan. Hasil penelitian menunjukkan bahwa, pemerintah kota Makassar tidak memiliki Peraturan Daerah (PERDA) khusus yang mengatur tentang Rencana Tata Ruang Wilayah (RTRW) Kota Makassar mengenai perlindungan lahan pertanian pangan berkelanjutan di Kota Makassar. Sementara adanya Peraturan Daerah Nomor 4 Tahun 2015 tentang Rencana Tata Ruang Wilayah di Kota Makassar yang menjelaskan ada kawasan peruntukan pertanian di Kota Makassar sebagai kawasan peruntukan pertanian, dijelaskan pada pasal 72 ayat (2) Kawasan peruntukan pertanian pangan ditetapkan disebagian wilayah Kecamatan Biringkanaya dengan luas 168,79 hektar tersebut, hanya sebagai rencana atau sebagai kawasan pertanian budidaya yang masih dalam tahap rencana, yang bisa kapanpun dialih fungsikan atau dikelola ke hal yang lain. Pemerintah Kota Makassar masih ditahap proses identifikasi kepemilik lahan pertanian yang ada di Kota Makassar dan masih di tahap penganggaran serta penyusunan rancangan pengadaan kawasan perlindungan lahan pertanian pangan berkelanjutan di Kota Makassar yang akan dimasukkan dalam persiapan peraturan daerah baru Kota Makassar.
\end{abstract}

Kata Kunci ; Kebijakan, perlindungan lahan, Pertanian.

\section{PENDAHULUAN}

Indonesia merupakan negara agraris, dimana pertanian merupakan basis utama perekonomian nasional. Sesuai dengan pembaharuan agraria dan aturan yang berlaku yang berkenaan dengan penataan kembali penguasaan, kepemilikan, penggunaan, dan pemanfaatan sumber daya yang ada dalam suatu wilayah, khususnya pada sektor 
pertanian itu sendiri, telah di tetapkan dalam peraturan Undang-Undang No. 41 Tahun 2009 tentang Perlindungan Lahan Pertanian Pangan Berkelanjutan, sebagai sistem dan proses dalam merencanakan dan menetapkan, mengembangkan, memanfaatkan dan membina, mengendalikan, dan mengawasi lahan pertanian pangan secara berkelanjutan.

Perlindungan lahan pertanian pangan merupakan bagian yang tidak terpisahkan dalam penataan ruang wilayah. Hal itu sesuai dengan Peraturan Pemerintah No. 1 Tahun 2011 tentang Penetapan kawasan dan Alih Fungsi Lahan Pertanian Pangan Berkelanjutan adalah bidang lahan pertanian yang ditetapkan untuk dilindungi dan di kembangkan secara konsisten, guna menghasilkan pangan pokok bagi kemandirian, ketahanan, dan kedaulatan pangan nasional.

Adapun yang ditetapkan untuk Kawasan Peruntukan Lahan Pertanian sebagai Kawasan Budidaya di Kota Makassar diatur dalam Peraturan Daerah No. 4 Tahun 2015 tentang Rencana Tata Ruang Wilayah Kota Makassar Tahun 2015-2023, dijelaskan pada pasal 72 yaitu tentang Kawasan Peruntukan Pertanian.

Kota Makassar sebagai Ibu Kota Provinsi Sulawesi Selatan tidak terlepas dari arus deras fenomena konversi lahan pertanian ke-non pertanian dimana hal tersebut dikatakan oleh Kepala Dinas Pertanian dan Perikanan (DP2) Makassar, Bapak Abd Rahman Bando (beritakotamakassar.fajar.co.id/ 2020/02/21) bahwa, luas hamparan lahan pertanian di Kota Makassar yang hilang dalam kurun waktu 10 tahun terakhir seluas 500 hektar. Data lahan untuk Sawah pada tahun 2008 itu luasnya 2.636 hektar, saat ini sisa 2039 hektar. Ada penurunan 500 hektar lebih dalam kurun waktu 10 tahun.

Dalam menghadapi pembangunan, di sektor pertanian masih terdapat banyak persoalan besar yang harus diselesaikan, salah satu diantaranya adalah permasalahan alih fungsi lahan pertanian menjadi lahan nonpertanian yang saat ini terus mengalami peningkatan. Alih fungsi lahan pertanian sebenarnya bukan masalah baru. Sejalan dengan adanya peningkatan jumlah penduduk serta meningkatnya kebutuhan infrastruktur seperti, perumahan, jalan, industri, perkantoran, dan bangunan lain, menyebabkan kebutuhan akan lahan meningkat. Selain itu, pertumbuhan ekonomi yang tinggi, menyebabkan pertumbuhan yang sangat cepat di beberapa sektor ekonomi. Pertumbuhan tersebut juga membutuhkan lahan yang lebih luas sehingga terjadi peningkatan kebutuhan lahan untuk pembangunan, sementara ketersediaan lahan relatif tetap menyebabkan persaingan dalam pemanfaatan lahan.(Puspasari 2012).

Menurut Ripley dan Frankin, dalam Maulana dan Nugroho (2019), memperkenalkan sebuah pendekatan "kepatuhan" dan pendekatan faktual dalam implementasi kebijakan. Berdasarkan pendekatan kepatuhan dan pendekatan faktual dapat dinyatakan bahwa keberhasilan kebijakan sangat ditentukan oleh tahap implementasi dan keberhasilan proses implementasi ditentukan oleh kemampuan implementor, yaitu: (1) kepatuhan implementor mengikuti apa yang diperintahkan oleh atasan, dan (2) kemampuan implementor melakukan apa yang dianggap tepat sebagai keputusan pribadi dalam menghadapi pengaruh eksternal dan faktor non organisasional, atau pendekatan faktual.

Kajian tentang perlindungan lahan pertanian telah banyak dilakukan sebelumnya oleh peneliti lainnya, begitupun juga tentang kajian implementasi kebijakan telah banyak ditulis oleh para ilmuan. Tetapi, kajian yang mencoba menyentuh perspektif implementasi kebijakan perlindungan lahan pertanian pangan berkelanjutan di kota Makassar belum perna disentuh untuk dijadikan sebagai bahan kajian atau penelitian. Kajian tentang implementasi kebijakan sendiri telah banyak dilakukan oleh peneliti lain dengan tema-tema berbeda, seperti kajian yang dilakukan oleh Randa Nurianansyah Putra (2015), dengan judul penelitian Implementasi Kebijakan Pengendalian Alih Fungsi Lahan Pertanian Di Kota Batu Sebagai Kawasan Agropolitan. Kajian lainnya dilakukan oleh Surjana (2017), tentang Implementasi Kebijakan Publik Dalam Pembangunan Ruang Publik Pantai Losari Makassar. Sebagaimana hasil penemuannya bahwa, kebijakan publik serta implementasinya merupakan sebuah program yang kompleks karena perlu melibatkan seluruh stakeholder, yaitu pihak pemerintah, publik dan swasta. Kebijakan publik terdiri dari banyak aktor dengan berbagai 
kepentingannya tetapi publik sebagai target sasaran sehingga menjadi aspek yang paling penting.

Kajian lain dengan tema yang berbeda dari Implementasi kebijakan, di teliti oleh Raden Wijaya (2020) dengan tema Implementasi Kebijakan Public Dalam Pengelolaan Dana Desa Di Kecamatan Martapura Kabupaten Ogan Komering Ulu Timur yang menyebutkan bahwa, keberhasilan implementasi suatu kebijakan akan ditentukan oleh hubungan dari masing-masing variabel atau faktor yang turut terlibat dalam implementasi. Lain halnya yang dilakukan Choiriyah (2018) yang meneliti dengan judul Implementasi kebijakan public Dalam Penanganan Kemiskinan Studi Implementasi Kebijakan Program Bantuan Langsung Tunai Di Kelurahan Kuto Batu Kecamatan Ilir Timur yang hasil penelitian menunjukkan bahwa, persoalan kemiskinan merupakan masalah yang sangat kompleks. Hak-hak dasar masyarakat antara lain, terpenuhinya kebutuhan pangan, kesehatan, pendidikan, pekerjaan, perumahan, air bersih, pertanahan, sumber daya alam dan lingkungan hidup, rasa aman dari perlakuan atau ancaman tindakan kekerasan dan hak untuk berpartisipasi dalam kehidupan sosial politik. Sedangkan judul penelitian lainnya yang dilakukan oleh Darmawati dan Choirul Saleh (2015) dengan judul penelitian yaitu Implementasi Kebijakan Rencana Tata Ruang Wilayah Dalam Persektif Pembangunan Berkelanjutan. Hasil penelitian menunjukkan bahwa, perencanaan tata ruang wilayah menjadi salah satu problematika pada perkembangan Kota dewasa ini, perkembangan kota yang cukup cepat dengan pertumbuhan penduduk yang cukup pesat juga, maka masalah lingkungan menjadi suatu masalah yang cukup urgen dalam pembahasan mengenai keberlanjutan lingkungan untuk masa depan generasi. Perencanaan tata ruang menjadi hal yang penting maka setiap wilayah Provinsi, Kota/ Kabupaten harus mempunyai aturan yang akan menjadi pedoman dalam penataan ruang dan menjadi acuan dalam pelaksaanaan pembangunan. Karena itu, implementasi kebijakan Perda RTRW merupakan acuan perencanaan penataan ruang wilayah berdasarkan arahan pemenfaatan ruang yang meliputi tiga hal yaitu: pertama; strategi perwujudan struktur ruang, kedua; perwujudan pusat kegiatan, dan ketiga; perwujudan sistem prasarana.

Sedangkan kajian tentang perlindungan lahan pertanian juga telah banyak dilakukan oleh peneliti sebelumnya dengan judul yang berbeda-beda, seperti halnya yang telah dilakukan oleh Gesthi Ika Janti (2016) dengan judul penelitian Perlindungan Lahan Pertanian Pangan Berkelanjutan Guna Memperkokoh Ketahanan Pangan Wilayah (Studi di Kabupaten Bantul, Daerah Istimewa Yogyakarta) yang menemukan bahwa, Kebutuhan lahan non pertanian cenderung mengalami peningkatan. Hal ini mendorong terjadinya alih fungsi lahan pertanian dan apabila tidak dikendalikan dapat mengancam ketahanan pangan. Adapun dengan judul penelitian yang berbeda dilakukan oleh Kusumastuti, Ayu Candra dan Lala M Kolopaking (2018), yang mengangkat persoalan Faktor yang mempengaruhi alih fungsi lahan pertanian pangan di kabupaten pandeglang. Hasil penelitian menunjukkan bahwa, faktor yang mempengaruhi alih fungsi lahan adalah luas penguasaan lahan, $\mathrm{B} / \mathrm{C}$ rasio usaha tani padi, dan kondisi jalan. Usaha menekan konversi lahan pangan memerlukan komitmen pemerintah dan masyarakat sebagai pelaku kebijakan. Pembentukan kelembagaan kawasan perdesaan berbasis bisnis komunitas lokal menjadi salah satu solusi dalam mencegah alih fungsi lahan pertanian pangan.

Sementara kajian lain dengan tema yang berbeda dari judul penelitian tentang perlindungan lahan pertanian diteliti oleh Sostenis Sampeliling, Santun R.P Sitorus dan Siti Nurisyah (2012) dengan tema penelitian Kebijakan Pengembangan Pertanian Kota Berkelanjutan Studi Kasus Di DKI Jakarta. Hasil analisis dari penelitian tersebut menemukan bahwa, kebijakan pengembangan pertanian perkotaan berkelanjutan di wilayah DKI Jakarta perlu dilakukan dengan pendekatan integratif dengan mempertimbangkan enam faktor kunci penentu keberlanjutan: (1) Luas pekarangan, (2) Pengembangan komoditas dan teknologi ramah lingkungan, (3) Penyuluhan dan kelembagaan pertanian, (4) Perluasan lahan/ruang usaha tani, (5) Kerjasama antar stakeholder, dan (6) Pemberian insentif pertanian. Opsi kebijakan adalah perluasan lahan/ruang usaha tani, pengembangan 
komoditas dan teknologi ramah lingkungan dan pengembangan kelembagaan pertanian. Hal lainnya penelitian yang dilakukan juga dilakukan oleh Irawan (2019) dengan judul penelitian Implementasi Kebijakan Pengendalian Alih Fungsi Lahan Pertanian Pangan Berkelanjutan Di Kecamatan Rimbah Melintang Kabupaten Rokan Hilir. hasil penemuannya meyebutkan bahwa, Faktorfaktor yang mempengaruhi implementasi adalah sosialisasi, petugas, dana, respon implementor, pemahaman terhadap kebijakan, peraturan pendukung, SOP, koordinasi antar instansi, komitmen pelaksanan, dan dukungan publik menunjukkan hasil yang tidak signifikan, karena implementasi UndangUndang No 41 Tahun 2009 dan peraturan turunannya PP Nomor 1 tahun 2009 berlaku secara nasional. Adapun kajian lainnya dengan pendekatan hukum yang dilakukan oleh Cahyaningrum (2019), dengan judul penelitian Perlindungan Hukum Terhadap Lahan Pertanian Pangan dari Pengalihan Fungsi untuk Non Pertanian Pangan. Dari Hasil penelitian menunjukkan bahwa, lahan pertanian pangan penting untuk dilindungi agar ketahanan pangan terwujud, hak rakyat atas pangan terpenuhi, meningkatkan kesejahteraan petani, dan menjaga kelestarian lingkungan hidup. Upaya untuk melindungi dilakukan secara preventif dan represif. Meskipun dilindungi, alih fungsi lahan pertanian pangan tetap terjadi. Beberapa penyebabnya: ketentuan pelindungan lahan pertanian pangan belum ditindaklanjuti, desakan kebutuhan lahan untuk kepentingan lain, dan rendahnya penghasilan petani. Beberapa upaya untuk mengatasinya: membuat regulasi teknis mengenai pelindungan lahan pertanian pangan, mengendalikan Lahan Pertanian Pangan Berkelanjutan, melindungi dan memberdayakan petani. Pemerintah/ pemerintah daerah harus melakukan segala upaya untuk melindungi lahan pertanian pangan dan menjadikan sektor pertanian menarik.

Perlindungan Lahan Pertanian Pangan Berkelanjutan di Kota Makassar sendiri tentunya memiliki keterbatasan lahan pertanian, akibat pemukiman dan penduduk yang terus bertambah. Lahan pertanian di Kota Makassar makin hari menyempit. hal ini pemerintah sebagai pemegang kebijakan, mesti memberikan perhatian besar dari segi perlindungan pada sektor pertanian itu sendiri, dengan mengimplementasikan kebijakan tentang perlindungan lahan pertanian pangan berkelanjutan, sebagaimana yang telah diatur dalam Undang-Undang No. 41 Tahun 2009 dengan menjaga dan mencegah terjadinya alih fungsi lahan pertanian yang makin sesak dan juga dilakukan untuk memanimalisir dampak kerugian baik dari segi kelestarian lingkungan untuk penyerapan air mengurangi dampak banjir, sebagai penyedia pangan untuk kehidupan sosial maupun juga untuk menambah pendapatan ekonomi daerah Kota Makassar.

Berdasarkan permasalahan yang terjadi diatas, maka peneliti tertarik melakukan penelitian tentang "Implementasi Kebijakan Perlindungan Lahan Pertanian Pangan Berkelanjutan Di Kota Makassar”.

\section{METODE}

Penelitian ini menggunakan pendekatan kualitatif, jenis penelitian yang temuantemuannya tidak diperoleh prosedur statistik atau bentuk hitungan lainnya. Pendekatan kualitatif dipilih karena dapat digunakan untuk mengungkap dan memahami sesuatu dibalik phenomena yang belum diketahui. Adapun jenis penelitian ini bersifat deskriptif, yaitu untuk mendeskripsikan dan mengkaji data yang diperoleh dari hasil wawancara mendalam (indepth intervew) observasi dan dokumentasi.

Penelitian ini dilaksanakan di Kantor Dinas Pertanian Kota Makassar, Dinas Penataan Ruang Kota Makassar, Badan Pertanahan Nasional Kota Makassar dan Kelompok Tani Kota Makassar. Lokasi ini dipilih dengan pertimbangan bahwa, Implementasi Kebijakan Perlindungan Lahan Pertanian Pangan Berkelanjutan di Kota Makassar masih kurang maksimal.

Adapun teknik yang dilakukan dalam mengimput data adalah sebagai berikut; wawancara, observasi dan studi dokumentasi dan langkah selanjutnya adalah melakukan proses analisis yaitu; reduksi data, menyajikan data, verifikasi data dan penarikan kesimpulan. Kemudian uji keabsahan datanya melalui; 
perpanjangan masa pengamatan, teknik meningkatkan ketekunan dan trianggulasi.

\section{HASIL DAN PEMBAHASAN}

Secara umum, penelitian ini menguraikan permasalahan dengan menelusuri aspek implementasi kebijakan Soren C. Winter pada perlindungan lahan pertanian pangan berkelanjutan di Kota Makassar. Teori ini mengarahkan pada 3 (tiga) variabel utama yaitu; a. Prilaku hubungan antar organisasi, yang dimensinya adalah komitmen dan koordinasi antar organisasi. b. Prilaku hubungan tingkat bawah, yang dimensinya adalah kontrol organisasi, etos kerja dan norma professional. c. Prilaku kelompok sasaran, yang meliputi respon positif atau negatif masyarakat. Serta ditambahkan dengan bagaimana Faktor Pendukung dan Faktor Penghambat dalam mengimplementasikan kebijakan perlindungan lahan pertanian pangan berkelanjutan di Kota Makassar.

Pada aspek Prilaku Hubungan Antar Organisasi, hasil penelitian menunjukkan bahwa, pemerintah kota Makassar dalam melakukan perlindungan lahan pertanian pangan berkelanjutan di Kota Makassar sebagaimana yang telah di tetapkan dalam peraturan Undang-Undang No. 41 Tahun 2009 tentang Perlindungan Lahan Pertanian Pangan Berkelanjutan. Ternyata Pemerintah kota Makassar selama ini tidak memiliki Peraturan Daerah (PERDA) yang mengatur tentang Rencana Tata Ruang Wilayah (RTRW) Kota Makassar mengenai perlindungan lahan pertanian pangan berkelanjutan di Kota Makassar.

Adapun komitmen pemerintah kota Makassar dalam hal ini Dinas Pertanian, masih sedang mengusahakan identifikasi kepemilik lahan pertanian yang masih ada di Kota Makasaar dan kini masih berada di tahap proses penganggaran serta penyusunan rancangan pengadaan kawasan Perlindungan Lahan Pertanian Pangan Berkelanjutan (LP2B) di Kota Makassar yang akan dimasukkan dalam persiapan Peraturan Daerah baru Kota Makassar.

$\begin{array}{llr}\text { Gambar 1. Hasil Penelitian } & \text { Dan } \\ \text { Pengelolahan Data } & \text { Kegiatan } \\ \text { Penyiapan Lahan } & \text { Pertanian } \\ \text { Pangan Berkelanjutan } & \text { Di Kota } \\ & \text { Makassar }\end{array}$

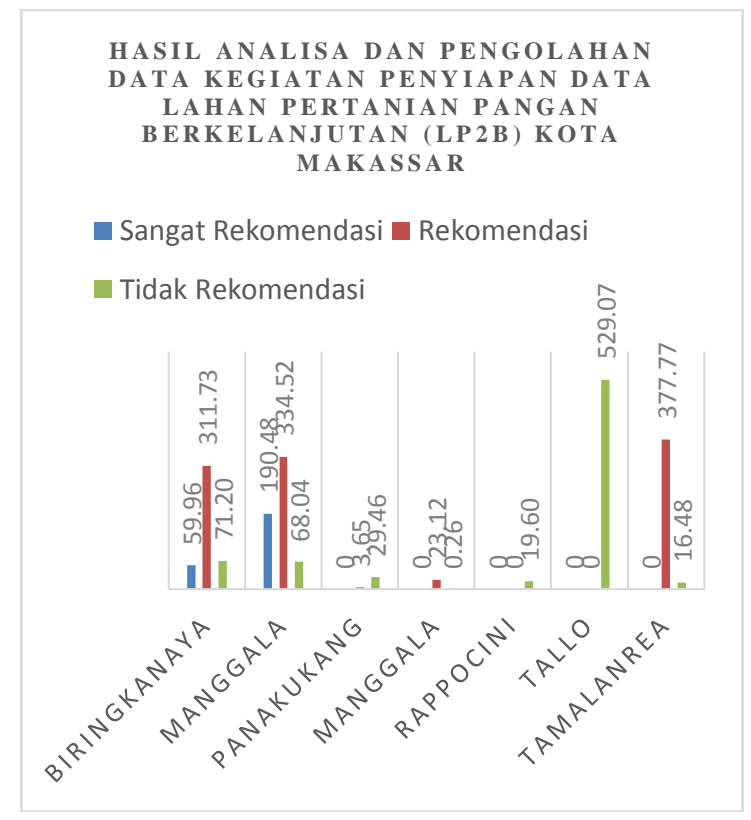

Sumber: Dinas Perikanan dan Pertanian Kota Makassar 2019

Dari grafik diatas menjelaskan bahwa, sudah ada hasil analisa dan pengolahan data kegiatan penyiapan data lahan pertanian pangan berkelanjutan (LP2B) di Kota Makassar di tahun 2019 yaitu, sangat direkomendasikan luas lahan sawah total 250,44 Ha, Direkomendasikan seluas 1.050,78 Ha dan tidak direkomendasikan seluas 734,11 Ha dari total luas lahan sawah yang ada di Kota Makassar seluas 2.035 Ha.

Sementara kordinasi antar organisasi yang dilakukan sesama instansi pemerintahan Kota Makassar selama ini, terkait dengan keberadaan Peraturan Daerah No 4 Tahun 2015 tentang Rencana Tata Ruang Wilayah di Kota Makassar sebagai kawasan peruntukan pertanian, yang dijelaskan pada pasal 72 ayat (2) Kawasan peruntukan pertanian pangan ditetapkan disebagian wilayah Kecamatan Biringkanaya dengan luas 168,79 hektar. Dinas Pertanian belum perna melakukan kordinasi sesama instansi lainnya. Karena selama ini Dinas Pertanian selaku penanggungjawab utama dalam hal 
perlindungan pertanian di Kota Makassar ternyata belum perna tahu akan keberadaan Peraturan Daerah No 4 Tahun 2015 tentang Rencana Tata Ruang Wilayah di Kota Makassar sebagai kawasan peruntukan pertanian tersebut.

Adapun semenjak di terbitkanya SK Kementrian Agraria dan Tata Ruang (ATR)/Badan Pertanahan Nasional (BPN) di tahun 2019 tentang penetapan Luas Lahan Baku Sawah dalam pembahasan persiapan pemetaan persiapan kawasan perlindungan lahan pertanian pangan berkelanjutan di Kota Makassar. Baru kembali mulai diadakan kordinasi sesama antar instansi yang terkait sebagai penanggung jawab dalam Tim RTRW untuk penyusunan rencana perlindungan lahan pertanian pangan berkelanjutan di Kota Makassar.

Dinas yang terkait dalam TIM RTRW penyusunan rencana perlindungan lahan pertanian pangan berkelanjutan di Kota Makassar tersebut diantaranya Dinas Perikanan dan Pertanian, Dinas lainnya yaitu Penataan Ruang, Badan Pertanahan Nasional, Dinas Lingkungan Hidup, Pihak Akademisi dan Badan Perencanaan Pembangunan Daerah Kota Makassar.

Kemudian pada aspek Prilaku Implementator Tingkat Bawah dalam hal control organisasi, pemerintah kota Makassar dalam hal ini Dinas Pertanian, memiliki petugas lapangan dalam melakukan pengontrolan dan pendampingan secara langsung yaitu, Dinas Pertanian memilik Pemimpin Pertanian Kecamatan (PPK) yang bertugas untuk memantau atau mengawasi secara rutin 2 (dua) kali dalam seminggu di setiap kegiatan para petani. Hal itu sebagaimana juga dijelaskan oleh pemimpin pertanian kecamatan kordinator Kecamatan Biringkanaya bahwa, Pemimpin Pertanian Kecamatan (PPK) yang ditugaskan kelapangan, itu bertugas 2 (dua) kali dalam seminggu untuk mengontrol setiap kegiatan kelompok tani di kota Makassar.

Dinas Pertanian memiliki 7 (tujuh) kordinator Pemimpin Pertanian Kecamatan (PPK) yang tersebar di 7 (tujuh) kecamatan yang masih tersisa lahan pertanian Kota Makassar yaitu Kecamatan Biringkanaya, Tamalanrea, Rappocini, Manggala, Tallo, Panakukkang dan Tamalate, yang bertugas di lapangan secara langsung untuk mengontrol para petani di Kota Makassar.

$\begin{array}{clrr}\text { Gambar 2. } & \text { Luas Lahan } & \text { (Ha) } & \text { Pertanian } \\ & \text { Perkecamatan } & \text { Di } & \text { Kota } \\ & \text { Makassar 2019 } & & \end{array}$

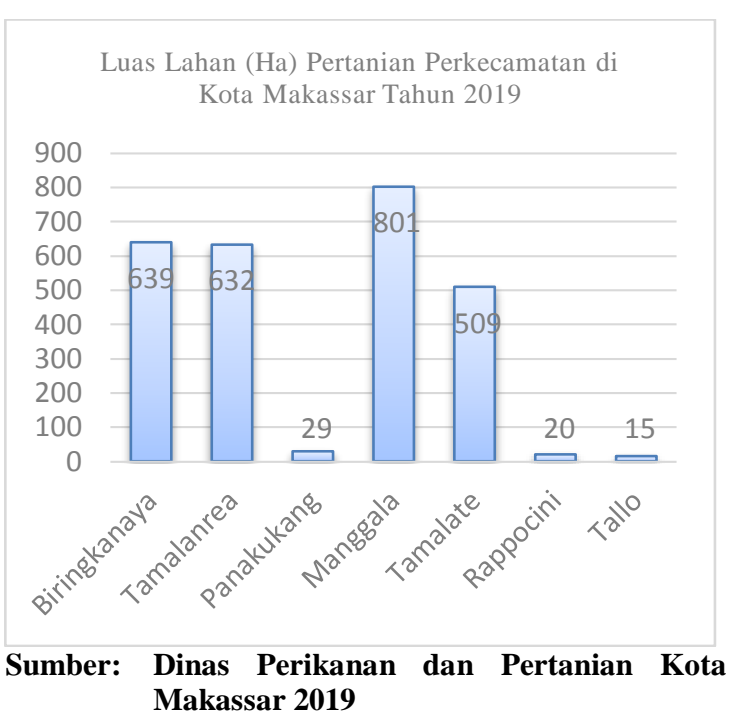

Dari grafik diatas menjelaskan bahwa, luas lahan sawah Perkecamatan Di Kota Makassar Tahun 2019 yaitu luas lahan sawah Kecamatan Biringkanaya 639 Ha, Tamalanrea $632 \mathrm{Ha}$, Panakukang $29 \mathrm{Ha}$, Manggala 801 Ha, Tamalate $509 \mathrm{Ha}$, Rappocini $20 \mathrm{Ha}$, dan Tallo 15 Ha. Jadi total luas lahan sawah secara keseluruhan Kota Makassar adalah 2.035 Ha.

Adapun untuk Etos Kerja selama ini yang dilakukan Pemerintah Kota Makassar bahwa, Pemerintah Kota Makassar dalam hal ini Dinas pertanian setiap tahunnya mengadakan pertemuan kepada seluruh petani di Kota Makassar di setiap acara besar musyawarah kelompok tani abbulo sibatang dan disetiap pertemuan, Dinas Pertanian selalu mensosialisasikan kepada para petani agar selalu menjaga dan melindungi lahan pertaniannya untuk tidak di alih fungsikan.

Dinas Pertanian tiap tahunnya membuat program peningkatan hasil produksi pertanian untuk petani di Kota Makassar dan setiap waktu memberikan pelatihan pemberdayaan pertanian, pembinaan pertanian dan juga bantuan untuk memenuhi kebutuhan para petani, seperti bantuan dalam bentuk benih, obat-obatan pertanian, alat- alat mesin pertanian seperti pompa air dan traktor, 
penggilingan padi, serta alat panen pertanian, pupuk subsidi dengan menggunakan kartu nani yang dibagikan oleh Dinas Pertanian. Selain dari itu, juga disediakan tempat pendistribusian pemasaran hasil pertanian kepada para petani di Kota Makassar.

Kemudian dalam persiapan perencanaan perumusan pembuatan kebijakan perlindungan lahan pertanian pangan berkelanjutan di Kota Makassar, Dinas Pertanian kota Makassar masih ditahap proses pendataan para petani dan akan memanggil seluruh para pemilik lahan pertanian di Kota Makassar untuk bisa dijadikan lahan pertaniannya sebagai lahan pertanian pangan berkelanjutan di Kota Makassar.

Sementara, mengenai norma profesional sebagai perwujudan sumber daya yang dimiliki, baik itu sumber daya manusia dan sumber daya finansial yang dimiliki pemerintah kota Makassar dalam melakukan perlindungan lahan pertanian berkelanjutan di kota Makassar. Dinas Pertanian memiliki kemampuan sumber daya manusia bidang Kasie Padi dan Palawija, yang menangani pertanian pangan di kota Makassar dan untuk petugas lapangan, Dinas Pertanian memiliki Pemimpin Pertanian Kecamatan (PPK) yang bertugas untuk mendata sekaligus mengontrol setiap aktiftas petani. Sementara untuk penangan teknisnya seperti dalam membudidayakan tanaman pertanian, Dinas Pertanian memiliki Penyuluh Pertanian Lapangan (PPL) yang ada disetiap perkelompok pertanian di Kota Makassar.

Dinas Pertanian juga memiliki tempat pertemuan antara PPK, PPL dan Petani di Balai Penyuluhan Pertanian (BPP) yang tersebar di dua wilayah. Yaitu, BPP Sudiang untuk kelompok tani khusus wilayah Kecamatan Biringkanaya, Tallo, dan Tamalanrea dan BPP Barombong untuk kelompok tani wilayah Kecamatan Rappocini, Manggala, Panakukkang dan Tamalate. Adapun saat ini jumlah kelompok tani yang terdaftar di Dinas Pertanian yaitu ada 70 kelompok pertanian pangan yang tersebar di 7 Kecamatan kota Makassar.

Sementara untuk kemampuan sumberdaya finansial, Dinas Pertanian memilik sumber pendanaan setiap tahunnya untuk setiap program kegiatan meningkatkan produksi pertanian di kota Makassar, yang bersumber dari APBN Pusat dan APBD kota Makassar. Dari dana APBN Pusat melalui Dana Alokasi Khusus (DAK) pertanian, berupa perbaikan jalan usaha tani, jaringan irigasi tersier seperti di kecamatan manggala dan barombong, dam parit, sumur pompanisasi dan pengadaan Alat Mesin (ALSIN) Pertanian. untuk dana APBD Kota Makassar kususnya di Dinas Pertanian, untuk memfasilitasi pengadaan bibit, pupuk pertanian dan obatobatan serta pengadaan pelatihannya untuk petani di Kota Makassar.

Mengenai sumber daya finansial yang dimiliki pemerintahan kota Makassar dalam hal ini Dinas Pertanian dalam memberikan bantuan kepada petani, itu tidak dilakukan secara keseluruhan. Artinya, bertahap dilakukan pemberian bantuan disetiap kelompok tani yang ada di kota Makassar. Karena, Dinas Pertanian memilik keterbatasan anggaran dan berdasarkan pernyataan Dinas Pertanian dalam hal ini kasie padi dan palawija bahwa, semenjak di tahun 2018, Pemerintah Kota Makassar tidak lagi mendapatkan bantuan Dana Alokasi Kusus dari APBN Pusat. Karena, untuk mendapatkan batuan kusus dari pemerintahan pusat, saat ini harus ada persyaratan memiliki Lahan Pertanian Pangan Berkelanjutan (LP2B). Sementara Kota Makassar sendiri tidak memilki Lahan Pertanian Pangan Berkelanjutan.

Adapun dalam aspek Perilaku Kelompok Sasaran, yaitu masyarakat petani dalam merespon adanya sosialisasi tentang perlindungan lahan pertanian pangan berkelanjutan di Kota Makassar menunjukkan bahwa, perlindungan lahan pertanian pangan berkelanjutan di Kota Makassar, sangat direspon positif oleh kelompok tani di Kota Makassar. Hanya saja, permasalahan disatu sisi yang di alami Kelompok pertanian di kota Makassar untuk mempertahankan lahan pertaniannya, tentunya terkendala dalam setatus kepemilikan lahan. Karena petani di kota Makassar, selain ada yang mengelola lahan yang bersengketa seperti yang dialami Kelompok tani Tegal Bekasi di Kecamatan Rappoci, status petani di kota Makassar ratarata hanya sebagai petani penggarap dan penyewa. Artinya, petani yang mengelolah lahan pertanian yang bukan milik pribadinya, tentu tidak bisa berbuat lebih dalam hal ini untuk tidak terjadinyanya alih fungsi lahan 
pertanian yang di kelola petani di kota Makassar.

Sementara untuk Faktor Pendukung Pemerintah Kota Makassar, Dinas Pertanian mengatakan bahwa, dengan adanya UU No 41 tahun 2009 tentang Perlindungan Lahan Pertanian Pangan Berkelanjutan, bisa dijadikan sebagai dasar Pemerintahan Kota Makassar dalam pembuatan Peraturan Daerah (PERDA) khusus untuk Perlindungan Lahan Pertanian Pangan berkelajutan (LP2B) Kota Makassar.

Peta lokasi penyebaran luas lahan pertanian yang dimiliki oleh Dinas Pertanian saat ini dalam rancangan tata ruang wilayah di kota Makassar, yang menunjukkan luas lahan pertanian Kota Makassar tersisa sebanyak 2.035 hektar yang tersebar 7 kecamatan di Kota Makassar, itu masih memiliki potensi untuk dijadikan sebagai lahan pertanian pangan berkelanjutan di Kota Makassar.

Untuk faktor pendukung yang lain, saat ini telah diterbitkannya SK Kementrian Agraria dan Tata Ruang/Badan Pertanahan Nasional Nomor 686/SK-PG-03.03/XII/2019 tentang penetapan luas lahan baku sawah nasional tahun 2019, yang bisa dijadikan sebagai dasar untuk mendorong Pemerintahan Kota Makassar dalam pembuatan Peraturan Daerah (PERDA) khusus untuk Perlindungan Lahan Pertanian Pangan berkelajutan (LP2B) Kota Makassar. Dinas Pertanian juga di dukung dengan Sumber Daya Manusia (SDM) yang sudah sangat berpengalaman dilapangan dalam melaukan pelatihan dan pendampingan terhadap petani di Kota Makassar.

Disisi yang lain, adapun Faktor Penghambat yang dialami pemerintah kota Makassar dalam melakukan perlindungan lahan pertanian pangan berkelanjutan di Kota Makassar yaitu, akibat laju pertumbuhan jumlah penduduk yang semain lama semakin pesat di Kota Makassar, yang tentunya kebutuhan akan pemukiman warga dan infrastruktur lainya pasti juga ikut bertambah. Sehingga, penomena alih fungsi lahan pertanian ke nonpertanian tidak bisa dipungkiri untuk di hindari. Karena, Pemerintahan kota Makassar terkendala akan tidak adanya peraturan pendukung yang bisa dijadikan dasar pegangan Dinas Pertanian untuk melakukan pelarangan agar tidak terjadinya transaksi jual beli lahan pertanian dan alih fungsi lahan pertanin ke non pertanian di Kota Makassar.

Gambar 3 Pergeseran Penggunaan Lahan (Ha) Pertanian Di Kota Makassar Tahun 2013 - 2019

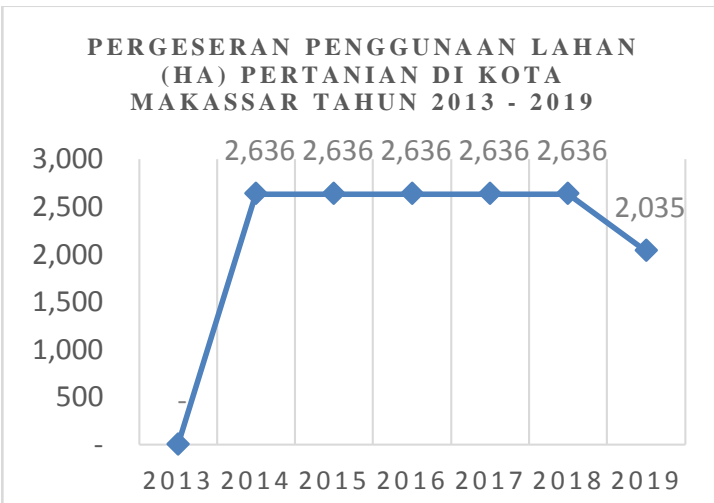

Sumber: Dinas Perikanan dan Pertanian Kota Makassar 2019.

Dari grafik diatas tampak bahwa, luas lahan sawah pada tahun 2013-2018 seluas 2.636 Ha. Sementara di tahun 2019 terjadi penurunan luas lahan sawah menjadi seluas $2.035 \mathrm{Ha}$. Berkurangnya luas lahan sawah ini disebabkan oleh adanya konversi atau alih fungsi lahan dari lahan pertanian ke non pertanian, baik untuk keperluan perumahan, fasilitas umum maupun property lainnya.

Lebih lanjut, mengenai faktor penghambat yang dialami Pemerintah Kota Makasar sebagaimana bardasarkan pernyataan Dinas Pertanian bahwa, status kepemilikan lahan pertanian di kota Makassar umumnya hanya sebagai petani penggarap, bukan sebagai pemilik lahan. Artinya petani yang hanya statusnya sebagai penggarap tidak bisa berbuat lebih, dalam hal ini untuk tidak terjadinya alih fungsi lahan pertanian ke fungsi yang lainnya. Karena petani bukan sebagai pemilik lahan. Adapun hambatan lain yang di alami Dinas Pertanian saat ini untuk menjaga lahan pertanian yang masih tersisa di kota Makassar yaitu masalah kurangnya anggaran untuk pertanian di Kota Makassar.

Belum lagi masalah yang di alami sebagai pemilik lahan pertanian sebagai mana penjelasan Kasie Penataan Ruang yaitu, selain karena lahan pertanian di kota Makassar terbatas akan saluran air irigasi teknis untuk memenuhi kebutuhan air pertanian di Kota 
Makassar, juga karena aspek pendapatan ekonomi nonpertanin lebih menjanjikan. Hal itu di pertegas dengan peryataan Kelompok Tani Tegal Bekasi bahwa, harga gabah sangat rendah dan itu membuat petani Makassar sulit sejahtera, sehingga lebih baik menjual lahan pertaniannya.

Adapun faktor penghambat selama ini, mengenai Peraturan Daerah (PERDA) RTRW No 4 Tahun 2015 Kota Makassar mengenai perutunkan kawasan pertanian di Kota Makassar, sebagaimana penjelasan Kepala Seksi Penataan Pertanahan Badan Pertanahan Nasional Kota Makassar bahwa, tidak ada kejelasan regulasi yang mengatur, dalam hal ini adalah titik sub zonasi wilayah mana saja budidaya kawasan peruntukan lahan pertanian yang dilindungi dan Kendala Pemerintahan dan pemerintah kota Makassar selama ini tidak bisa melakukan teguran atau pelarangan akan terjadinya transaksi jual beli dan alih fungsi lahan pertanian di Kota Makassar, karena tidak adanya peraturan pendukung untuk dijadikan dasar.

\section{KESIMPULAN}

Berdasarkan hasil pembahasan diatas, maka dapat diperoleh kesimpulan sebagai berikut :

a. Pada aspek prilaku hubungan antar organisasi yaitu: Komitmen pemerintah kota Makassar dalam hal ini Dinas Pertanian dalam melindungi lahan pertanian pangan berkelanjutan di kota Makassar. peneliti menyimpulkan bahwa, Dinas Pertanian masih ditahap proses identifikasi status kepemilik lahan pertanian yang ada di Kota Makassar dan masih di tahap penganggaran serta penyusunan rancangan pengadaan kawasan Perlindungan Lahan Pertanian Pangan Berkelanjutan (LP2B) di Kota Makassar yang akan dimasukkan dalam persiapan Peraturan Daerah baru Kota Makassar. Adapun kordinasi antar sesama intasi pemerintahan di Kota Makassar yang dilakukan selama ini dalam melakukan perlindungan lahan pertanian pangan berkelanjutan di Kota Makassar masih belum efektif, karena masih terjadi perbedaan pendapat diantara sesama instansi yang terkait. Adapun saat ini,
Dinas Pertanian baru mulai kembali adakan kordinasi sesama antar instansi pemerintahan yang terkait dalam Tim RTRW untuk penyusunan rencana perlindungan lahan pertanian pangan berkelanjutan di Kota Makassar.

b. Aspek perilaku implementator tingkat bawah yaitu: control organisasi yang dilakukan selama ini oleh pemerintah Kota Makassar dalam hal ini Dinas Pertanian, sudah ada dilakukan pengontrolan kepada petani disetiap mendekati musim tanam, menanam dan setelah musim tanam. Adapun etos kerja Dinas Pertanian untuk memenuhi kebutuhan para petani yang masih ada di Kota Makassar, juga sudah sangat baik. Sementara untuk norma professional yang dilakukan Dinas Pertanian untuk sumber pendanaan setiap tahunnya, untuk setiap program kegiatan meningkatkan produksi pertanian di kota Makassar selama ini bersumber dari APBN Pusat dan APBD kota Makassar. Hanya saja, Pemerintah Kota Makassar saat ini tentunya mengalami keterbatasan anggaran untuk pertanian. Karena Pemerintah Kota Makassar semenjak tahun 2018 tidak lagi mendapatkan bantuan Dana Alokasi Kusus (DAK) ditiap tahunnya dari APBN Pusat dibidang pertanian. Karena Kota Makassar tidak memilki Lahan Pertanian Pangan Berkelanjutan (LP2B) yang menjadi syarat untuk mendapatkan bantuan dari Pemerintah pusat.

c. Aspek prilaku kelompok sasaran yaitu: respon positif dan respon negatif dari masyarakat petani kota Makassar dalam mendukung atau tidak mendukung akan adanya kebijakan perlindungan lahan pertanian pangan berkelanjutan di Kota Makassar dimana peneliti menyimpulkan bahwa, Kelompok petani di Kota Makassar sangat merespon positif tentang adanya pemberitahuan mengenai perlindungan lahan pertanian pangan di Kota Makassar. Hanya saja permasalahan disatu sisi yang di alami Kelompok pertanian di kota Makassar untuk mempertahankan lahan pertaniannya, tentunya terkendala dalam setatus kepemilikan lahan. Karena petani di kota Makassar, selain ada yang mengelola 
lahan yang bersengketa, seperti yang dialami Kelompok tani Tegal Bekasi di Kecamatan Rappoci, status petani di kota Makassar rata-rata hanya sebagai petani penggarap dan penyewa.

d. Adapun Faktor pendukung dan Faktor penghambat yang dialami pemerintah Kota Makassar dalam proses perlindungan lahan pertanian pangan berkelanjutan yaitu; untuk faktor pendukung, Kota Makassar sudah memiliki data spasial peta lokasi penyebaran luas lahan pertanian dalam rancangan tata ruang wilayah, dimana kota Makassar memiliki potensi lahan pertanian yang tersisa seluas 2.035 hektar yang tersebar di 7 kecamatan di Kota Makassar dan Dinas Pertanian di dukung dengan Sumber Daya Manusia (SDM) yang sudah sangat berpengalaman dilapangan. Serta telah diterbitkannya SK Kementrian Agraria dan Tata Ruang/Badan Pertanahan Nasional Nomor 686/SK-PG-03.03/XII/2019 tentang penetapan luas lahan baku sawah nasional tahun 2019 yang bisa dijadikan sebagai dasar untuk mendorong Pemerintahan Kota Makassar dalam pembuatan Peraturan Daerah (PERDA) khusus untuk Perlindungan Lahan Pertanian Pangan berkelajutan (LP2B) Kota Makassar. Sementara yang menjadi faktor penghambat selama ini dalam melakukan perlindungan lahan pertanian pangan berkelanjutan di Kota Makassar yaitu, akibat penambahan jumlah penduduk semakin pesat yang tentunya kebutuhan akan pemukiman dan infrastruktur lainya pasti juga ikut bertambah dan Pemerintah kota Makassar selama ini tidak memiliki peraturan pendukung untuk dijadikan dasar melakukan tindakan pencegahan agar tidak terjadinya transaksi jual beli dan alih fungsi lahan pertanin ke non pertanian di Kota Makassar. Belum lagi, lahan pertanian di kota Makassar tidak memiliki pemerataan saluran air irigasi teknis untuk memenuhi kebutuhan air pertanian yang tersebar di Kota Makassar. Adapun masalah kurangnya anggaran untuk pertanian di Kota Makassar yang menjadi hambatan lain yang di alami
Dinas Pertanian saat ini, untuk menjaga lahan pertanian yang masih tersisa di Kota Makassar.

\section{REFERENSI}

Cahyaningrum, Dian. 2019. "Pelindungan Hukum Terhadap Lahan Pertanian Pangan Dari Pengalihan Fungsi Untuk Non Pertanian Pangan (Legal Protection of Food Agricultural Land from Conversion to Non-Food Agricultural Land)." Negara Hukum: Membangun Hukum Untuk Keadilan Dan Kesejahteraan 10(1):27-48.

Choiriyah. 2018. "Implementasi Kebijakan Publik Dalam Penanganan Kemiskinan; Studi Implementasi Program Bantuan Langsung Tunai (Blt) Di Kelurahan Kuto Batu Kecamatan Ilir Timur II.” Islamic Banking: Jurnal Pemikiran Dan Pengembangan Perbankan Syariah 3(2):17-30.

Darmawati, Choirul Saleh, Imam Hanafi. 2015. "Implementasi Kebijakan Rencana Tata Ruang Wilayah (Rtrw) Dalam Perspektif Pembangunan Berkelanjutan.” Jurnal Ilmu Sosial Dan Ilmu Politik 4(2):378-84.

Irawan, Aca. 2019. "Implementasi Kebijakan Pengendalian Alih Fungsi Lahan Pertanian Pangan Berkelanjutan Di Kecamatan Rimba Melintang Kabupaten Rokan Hilir." Kemampuan Koneksi Matematis (Tinjauan Terhadap Pendekatan Pembelajaran Savi) 1(2):114.

Janti, Gesti Ika. 2016. "PERLINDUNGAN LAHAN PERTANIAN PANGAN BERKELANJUTAN GUNA MEMPERKOKOH KETAHANAN PANGAN WILAYAH (Studi Di Kabupaten Bantul, Daerah Istimewa Yogyakarta)." Jurnal Ketahanan Nasional 22(1):1.

Kusumastuti, Ayu Candra, Lala M Kolopaking, dan Baba Barus. 2018. "Faktor Yang Mempengaruhi Alih Fungsi Lahan Pertanian Pangan Di Kabupaten Pandeglang." Sodality: Jurnal Sosiologi Pedesaan 6(2):131-36.

Maulana, Delly, and Arif Nugroho. 2019. KEBIJAKAN PUBLIK Cara Mudah 
Memahami Kebijakan Publik. Banten: CV. AA. RIZKY.

Puspasari, Anneke. 2012. "FAKTOR-

FAKTOR YANG MEMPENGARUHI ALIH FUNGSI LAHAN PERTANIAN DAN DAMPAKNYA TERHADAP PENDAPATAN PETANI (Studi Kasus Desa Kondangjaya, Kecamatan Karawang Timur, Kabupaten Karawang)." Institut Pertanian Bogor.

Putra, Randa Nurianansyah. 2015. "Implementasi Kebijakan Pengendalian Alih Fungsi Lahan Pertanian Di Kota Batu Sebagai Kawasan Agropolitan.” Kebijakan Dan Manajemen Publik Volume 3(2):71-80.

Raden Wijaya, Rezky Aprilia. 2020. "Implementasi Kebijakan Publik Dalam Pengelolaan Dana Desa Di Kecamatan Martapura Kabupaten Ogan Komering Ulu Timur." Kebijakan Pemerintahan 3(2):75-83.

Sostenis Sampeliling, Santun R.P. Sitorus, Siti Nurisyah, dan Bambang Pramudya. 2012. "Kebijkan Pengembangan Pertanian Kota Berkelanjutan Studi Kasus Di DKI Jakarta." Analisis Kebijakan Pertanian 10(3):257-67.

Surjana, Ondang. 2017. "Implementasi Kebijakan Publik Dalam Pembangunan Ruang Publik Pantai Losari Makassar.” Jurnal Rekayasa Hijau 1(1):53-61.

Undang-undang Nomor 41 Tahun 2009 tentang Perlindungan Lahan Pertanian Pangan Berkelanjutan

Peraturan Pemerintah Nomor 1 Tahun 2011 tentang Penetapan Kawasan dan Alih Fungsi Lahan Pertanian Pangan Berkelanjutan

Peraturan Daerah Nomor 4 Tahun2015 tentang Rencana Tata Ruang Wilayah Kota Makassar tahun 2015-2023

http://beritakotamakassar.fajar.co.id/berita/202 0/02/21/lahan-pertanian-makassartergerus-500-ha/ 